\section{Bacon jako}

\section{Aristotelưv dědic}

BACON AS ARISTOTLE'S HEIR

\section{KAROLÍNA JIRÁKOVÁ}

Fakulta filozofická

Západočeská univerzita v Plzni

Sedláčkova 38

30614 Plzeň

kjirusko@kfi.zcu.cz

\section{ABSTRAKT}

Bacon himself calls his work The New Organon. He draws attention to the fact that Aristotle's set of logical and methodological writings, traditionally called Organon, is not the right way of acquiring knowledge. Between Bacon's new method and Aristotle's system are at first sight many apparent differences. A closer look could reveal that the border between them is not as sharp as it appears. The aim of this study is to highlight some of theirs similarities mainly with focus on their strong metaphysical belief that behind things we are able to reveal something common and constitutional for them. Even so sharp a difference between Aristotle and Bacon, as their evaluation of common beliefs as starting points of inquiry or question what is the goal of theoretic activity surely is, is defocused in this paper. This creates the reason why I prefer to call Bacon rather an Aristotle's heir than his opponent." 
Text je členěn do tří hlavních oddílů. V prvním z nich je zvažován vztah Bacona a Aristotela v širším kontextu. Aristotelův odkaz je zde tematizován jako součást myšlenkového dědictví, se kterým se Bacon musí vypořádat. Postupně se vyjasňuje, proč Bacon Aristotelovi připisuje výlučné místo a proč se právě proti němu musí vymezit.

Ve druhém oddílu se proto perspektiva zkoumání vztahu mezi Baconem a Aristotelem zužuje. Pro oba autory je nezbytné při zkoumání vycházet od jednotlivých věcí, a proto zde nabízím metaforu dvou pozorovatelů, na které ukazuji, jaké místo a cíl oba myslitelé připisují teoretické činnosti. $\mathrm{Z}$ takto postavené základny se pak přesunuji k oddílu třetímu, ve kterém jsou zvažovány a porovnávány vybrané metafysické a metodologické aspekty obou autorů. V části nazvané Aristotelovy a Baconovy jednotliviny a formy bych chtěla ukázat, že oba autoři sdílejí podobný koncept obecnin, ale naopak se velmi liší podoba jejich východisek. To je i důvodem, proč těmto startovním bodům poznání budu věnovat více prostoru než formám.

Text je svým charakterem spíše esejistický. Vlastní způsob práce je možné dobře ilustrovat na prvním oddílu, věnovaném předchůdcům. Co pro Bacona znamenají staří myslitelé? Na základě jeho vlastních myšlenek ukazuji negativní i pozitivní stránku tohoto vztahu. V tomto smyslu jsem inspirována prací Dialektika osvícenství od Adorna a Horkheimera, jejichž úvahy ovlivnily i způsob čtení Baconova díla. 
Oba autoři hovoří o osvícenství jako o určitém přístupu člověka ke světu a neidentifikují jej pouze s konkrétním historickým obdobím. Bacona používají jako reprezentativní příklad, ve kterém spatřují hlavní rysy osvícenského typu myšlení, a to jak v pozitivním smyslu slova, tak i v negativním. Nicméně v myšlení Adorna a Horkheimera jsou oba, Aristotelés i Bacon, osvícenskými mysliteli. Rozdíl v jejich racionalistickém přístupu ke světu se pokusím vysvětlit na jejich hodnocení místa teorie ve vědeckém myšlení.

Druhým inspirativním zdrojem pro tento text je Patočkova esej věnovaná Baconovi z knihy Aristotelés, jeho predchůdci a dědicové. Patočkův text na několika stranách čtenáře upozorňuje na nejednoznačný vztah mezi Aristotelem a Baconem a snaží se ukázat na některé aspekty, které právě z Bacona činí pravého nástupce antického filosofa, jakkoli se jejich vztah může jevit na první pohled opačně, tedy jako vztah předchůdce a překonavatele staré tradice. Jak Patočkův text, tak Dialektika osvícenství sehrály prvotní inspirativní úlohu pro moji snahu znovu tematizovat vztah mezi oběma myšlenkovými světy, Aristotelovým a Baconovým.

Zpřítomníme-li v duchu dialektiky oba aspekty, tedy pozitivní i negativní stránku vztahu mezi Baconem a tradicí, jaké to přináší výsledky? Baconův vztah $\mathrm{k}$ předchůdcům se ukazuje jako velmi nejednoznačný a komplikovaný. Na základě četby ho již nelze považovat za radikálního odpůrce staré filosofie. Právě jeho kritická reflexe zděděného myšlení ukazuje, jak důležitou roli hraje starší myšlení v jeho vlastním uvažování. Zakládá totiž možnost formulovat jeho vlastní program. Baconova snaha o odpoutání se od starších myšlenkových konceptů jej k této tradici, na první pohled možná paradoxně, připoutává. V této studii bych chtěla za pomoci stejného klíče poukázat na některé další momenty, které z Bacona utváří spíše Aristotelova dědice než protivníka.

\section{BACONU゚V PROJEKT A FILOSOFICKÉ dĚDICTVí}

Vztah Bacona nejen k Aristotelovi, ale k odkazu řeckých myslitelů vůbec je prodchnut rozhodnutím, které si vezme za své nejeden $\mathrm{z}$ mužů nastupujícího věku. Je to rozhodnutí odpoutat se od tradič-


nás na původní význam upomíná řecké slovo -, po které se bude poznání ubírat. A je to právě Baconovo myšlení, od kterého dále „kouzelné slovo metoda se usídluje v centru moderního uvažování. Metoda znamená zmnohonásobení duševních sil člověka, schopných prorazit k jádru věcí“.

Proti přeceňování a spoléhání se na odkaz antických myslitelů se Bacon postavil v první, kritické části spisu Nové organon ${ }^{2}$, který měl být součástí rozsáhlého projektu Velikého obnovení věd. ${ }^{3}$ „[...] ta část mého Obnovení věd,

\footnotetext{
Patočka 1964, s. 298.

$\checkmark$ textu je použiván český překlad od Miroslava Zůny.

Pro vlastní práci s textem byl použit též anglický prekelad díla Nové organon $z$ edice Cambridge Texts in the History of Philosophy.

3 Podrobně se k Baconovu plánu a rozložení témat vyjadřuje $v$ úvodní stu-
} 
která je věnována negativní kritice. Skládá se z trojího vyvrácení, a to: za prvé $\mathrm{z}$ důkazu, že přirozený lidský rozum nelze ponechat sám sobě, za druhé z vyvrácení důkazů a za třetí z vyvrácení teorií, neboli filozofických systémů a učení, jež jsou považovány za správné.“ (NO I,115)

Z odkazu řeckých filosofů vyrůstá dle Bacona spletitý svět pojmů a myšlenek, který existuje sám pro sebe a jehož vztah ke skutečnému světu je více než komplikovaný. Platónovy ani Aristotelovy úvahy nepřispívají k pochopení světa. Přesto Bacon nepožaduje, aby se zcela upustilo od spekulativní filosofie pocházející z antického dědictví, nýbrž navrhuje, aby vedle sebe existovaly dva způsoby filosofie. Samozřejmě především ten, který je teprve potřeba ustanovit: „[...] abychom tak pro myšlení otevřeli a zabezpečili novou a jistou cestu, jež počíná u samotných smyslových vjemů. Že je to nutné, to viděli bez vší pochyby i ti, kteří přisuzovali takovou důležitost logice.“ (NO I,74)

Tyto dvě filosofie by spolu mohly existovat současně a navzájem se podporovat. Ačkoli se na myšlenkách předchůdců ukazují různé druhy překážek bránících poznání v Baconem nově stanoveném smyslu slova, naprosté opuštění tradice je i pro Bacona jen těžko představitelné. „Bylo by nespravedlivé, kdyby se někdo o mně domníval, že chci zničit a zrušit ty filozofie a ta umění, jichž dnes užíváme; právě naopak, leží mi na srdci jejich

dii k Novému organu Jardineová, srov. Jardine 2000, s. xiii. užitečnost, pěstování i vážnost. Nechci totiž vůbec překážet tomu, aby vzrůstaly a nadále byly předmětem diskusí, aby byly ozdobou projevů, aby se jich používalo na profesorských stolicích a aby vzkvétaly $k$ prospěchu občanského života, a konečně aby obíhaly se souhlasem všech lidí jako jakési mince." (NO I,128) Baconovi jde o to, aby se tak dělo ze strany člověka uvědoměle, lidé musí porozumět rozdílu mezi požadavkem na poznání vedoucí lidstvo kupředu a společensko-kulturní rovinou sdílení tradičního odkazu. Tento úkol si bere Bacon za vlastní a ujímá se role průvodce (NO I, 32).

Podle Bacona se řečtí myslitelé nalézali na počátku dějin lidského vědění a pro své „mládí“ neměli k dispozici stejné poznatky a možnosti, kterými disponují myslitelé žijící na prahu novověku. „V onom věku byla totiž znalost času i světa omezená a skrovná; je to nejhorší zvláště pro ty, co zakládají všechno na zkušenosti.“ (NO I,72) Bacon nezapomíná připomínat, kdo je jeho hlavním nepřítelem, ale současně i partnerem. Jsou to ti z myslitelů, kteří se zajímali o přírodní filosofii a pro které byla vodítkem jednotlivá lidská zkušenost se světem. Jsou to právě oni, $\mathrm{v}$ jejichž šlépějích kráčí. Proto je hlavním terčem kritiky Aristotelés, nikoli Platón. V Baconových očích je to právě Aristotelés, kdo se nejvíce zpronevěřuje svému úkolu, když ustanovil svůj pojmový aparát, za pomoci kterého svět popisuje. Bacon Aristotela podezřívá, zda jsou jeho pojmy skutečně v přímém vztahu s pozorovaným přírodním světem, nebo byly vytvořeny již dopředu 
a vše se do nich musí vejít. „Ale samy pojmy a principy - kde ty se vzaly? “4

Skutečné vědění vzniká až po dostatečném čase. Pro Bacona je dokladem posunu vpřed především objevení Nového světa a hrdost na nové technické výdobytky. „V našich dobách je však známa většina částí Nového světa i nejzazší končiny světa starého a zásoba zkušeností nesmírně vzrostla.“ (NO I,72) Dále jsou pro Bacona důkazy pokroku především vynálezy tiskařského lisu, střelného prachu a kompasu. „Tyto tř̀i objevy změnily tvářnost i stav věcí na celém světě: první v písemnictví, druhý ve vojenství a třetí pokud jde o námořní plavbu. Vedly $\mathrm{k}$ nesčetným změnám a žádná vláda, ani filozofická škola, ani hvězda neměly takový vliv a účinek na lidské záležitosti jako tyto mechanické objevy.“ (NO I,129) Nezapomíná však ani na kritiku, mnohdy se o vynález věci spíše zakoplo, než že by byl výsledkem systematického úsilí (NO I,110). ${ }^{5}$ Tak se odkrývá jeden z hlavních nároků

$4 \quad$ Patočka 1964, s. 295.

Není to však jen kritický tón, který nalézáme $v$ Baconově hodnocení předchůdců. Pochvalně se vyjadřuje například o Hérakleitovi z Efesu, na kterého odkazuje, když vysvětluje idoly jeskyně: „Správně to formuluje Hérakleitos, když říká, že lidé hledají vědění ve svých malých světech, a nikoli ve světě velkém či obecném." (NO I,43) Navíc tato pasáž čtenáře upozorňuje, že se Bacon o jednotlivé nauky filosofư zajímá a odkazuje na konkrétní místa a myšlenky (srov. výše citovanou pasáž NO I,43 např. se zlomkem $D K 22$ B 2, B 72, B 89, B 114). Lze z toho usuzovat, že dávní myslitelé jsou skutečně jeho předchůdci, nití, kterou není možno jednoduše odstřihnout.

5 Tento nahodilý rys objevů z Baconova díla doslovně citují Adorno s Horkheimerem v první kapitole své společné knihy
Baconova vědeckého programu: zkoumání musí přinášet výsledky.

Baconův požadavek je postaven jak proti rétorické kráse mluveného slova, tak proti teoretickému zpo̊sobu rozvažování pro sebe samé (at'je sebehlubší). ${ }^{6}$ Plynou snad z těchto aktivit hmatatelné výsledky? Proto Bacon hovoří o řeckých myslitelích jako o chlapcích: rádi si popovídají, ale nejsou schopní nic zplodit, „nebot' jejich moudrost je pouze ve slovech a neplodná, pokud jde o díla“ (NO I,71). Důraz Řeků na rétorickou stránku Bacona popuzuje a má k tomu i hlubší důvod, než že $\mathrm{z}$ takové aktivity neplynou žádné výdobytky. Řeč, $\lambda o ́ \gamma o \varsigma$, již pro něj není zrcadlem, ve kterém se svět odrážel Řekům. Jemnost přírody přesahuje jemnost a možnosti argumentace (NO I,10, 24). ${ }^{7}$

Rozhodnutí vymezit se proti dosavadní tradici a výkladům umožňuje na jednu stranu Baconovi formulovat

Dialektika osvícenství; srov. Adorno, Horkheimer 2009, s. 17.

Místo objevů a vynálezů v Baconově myšlení rozebírá zajímavě Špelda 2016, s. 166. Období vynálezů jako Baconovu inspiraci viz v Jardine 2000, s. ix-xxii.

6 Toto místo se může jevit v protikladu $\mathrm{k} j \mathrm{již}$ zmíněnému postoji, že ani Bacon sám si nedokáže představit naprosté odstřižení od starších myšlenkových konceptů. Nemusíme však tato dvě místa chápat jako navzájem se vylučující. Domnívám se, že Bacon zde ukazuje, v čem spočivá jádro jeho kritiky vzhledem k možnostem vědeckého zkoumání a jeho využití, přičemž předchozí úvaha o nutnosti zachování starého odkazu přesahuje oblast vědy a reflektuje širši společensko-kulturní rovinu. Děkuji tímto recenzentovi za jeho připomínku k tomuto místu. „Nebot́ slovo ví, že je slabší než příroda, kterou oklamává.“ (Adorno, Horkheimer 2009, s. 76) 
vlastní - nový - postup. Na druhou stranu se $v$ jistém smyslu $k$ dědictví připoutává. Aby se mohl Bacon proti dávným myslitelům postavit, musí se s jejich odkazem nejdříve vyrovnat, porozumět jim natolik, aby mohl říci: takto k problému přistupovali staří myslitelé, ale já přicházím s novým řešením. Bacon ale především vysvětluje, proč je nutné zvolit zcela jiný způsob řešení. Proto lze říci, že ve chvíli, kdy Bacon formuluje své vlastní myšlenky o metodě v díle Nové organon, je za nimi vzápětí možné vyčíst, na jakém základě jsou formovány, vůči komu jsou postaveny. Je to právě radikální požadavek na rozchod s tradicí, který tradici navždy činí tichým Baconovým partnerem.

Bacon sám pojmenoval své dílo tak, aby zdůraznil, že soubor Aristotelových logických a metodologických spisů, tradičně nazývaný jako Organon, není tou pravou cestou. Ale jakou cestu (metodu) zde vlastně Bacon kritizuje? Nezapomeňme na všeobecně známý rozpor mezi Aristotelem navrhovanou metodou a jeho vlastními filosofickými postupy, který zaměstnává badatele po staletí. ${ }^{8}$ Je si této diference Bacon vědom? At' již ano, či ne, oproti Aristotelovi se Baconova metoda zdá být jako návod jasnější, a o to také razantnější odpovědí na úvahy řeckého filosofa. Bacon si je ve

Proměny a výsledky této diskuse zachycuji vybrané texty aristotelských badatelů vydané v českém překladu pod názvem Epagógé a epistémé (2004). Současné hodnocení Aristotelovy vědecké metody a jejího místa $v$ dějinách západní vědy lze ilustrovat na studii Scientific Method uveřejněné na portálu Stanford Encyclopedia of Philosophy (Andersen, Hepburn 2016). svém textu jistý, představuje svůj projekt jako „dobrou zvěst" pro každého člověka (at' již bude vědcem, či jen uživatelem plodů vědecké činnosti). Aristotelés naopak na mnohých místech váhá či odkazuje čtenáře s odpovědí na otázku na jiné místo svých zkoumání. ${ }^{9}$

Mezi požadavkem nové metody a aristotelskou tradicí je celá řada na první pohled patrných rozdílů. Při bližším pohledu se hranice mezi nimi již tak ostře jevit nemusí. Vztah mezi Baconovou a Aristotelovou metodou je komplikovanější, než se může na první pohled zdát. Rozdíly zdůrazňuje ve svém výkladu například Špelda, když hovoří o formě, kterou hledá Bacon a kterou představuje ve svých spisech Aristotelés. ${ }^{10}$ Naproti tomu Röd ve své knize přistupuje ke srovnání metafysických východisek obou autorů opatrněji a poukazuje na některé podobné rysy. ${ }^{11}$

9 Takto se jeví srovnání obou filosofických projektů mně, protože mám zkušenost především se subtilností Aristotelových textů. Badatelé, kteři se zabývají především Baconem, vidí nejasnosti i v jeho projektu a podávají o něm různé výklady, srov. např. Špelda 2009, s. 86 nebo Jardine 2000, s. xxiv-xxv.

Matthews ve své knížce zdůrazňuje, že nalézáme různé interpretace Baconova projektu proto, že každá následující generace ho vykládá skrze vlastní dobově podmíněnou optiku. Srov. Matthews 2008, s. 117. Matthews má jistě pravdu, ale jeho tvrzení lze vztáhnout v našem připadě i na Aristotela a každého dalšího myslitele. V souvislosti s mojí studií rozumím této myšlence spíše ve smyslu upozornění a varování, na snahu porozumět metafysickému jádru na základě podrobné četby obou autorů však nerezignuji.

10 Srov. např. Špelda 2009, s. 86.

11 Srov. např. Röd 2001, s. 24, 31, 32.

Nabízí se námitka, že oba texty, jak Rödův, tak i špeldův, jsou svým charakterem 
Možný návrh řešení těchto zdánlivých protikladů citlivě ${ }^{12}$ popisuje Bacon: „Pokud se týče filozofie a věd, je jeden velký a takřka základní rozdíl mezi nadáními, že totiž jedni mají spíše větší nadání pro to, že postřehnou na věcech rozdíly, jiní opět, že na nich vidí podobnosti. Myslitelé klidní a bystří dovedou soustředit své úvahy a umějí se pozdržet a zastavit u každého sebejemnějšího rozdílu, naopak myslitelé, kteří vidí věc $\mathrm{z}$ nadhledu a postupují od jedné věci $\mathrm{k}$ druhé, rozpoznávají i ty nejnepatrnější a nejobecnější podobnosti na věcech a skládají je dohromady. Obojí nadání však může snadno upadnout do krajnosti, jedno vidí všude jenom rozdílnosti, druhé podléhá př́iliš fantazii." (NO I,55) S pomocí tohoto rozlišení se v textu pokusím o spojení obou pohledů i s vědomím rizika, že poukáži na ty prvky v myšlení Aristotela a Bacona, které by jinému čtenáři připadaly ne příliš patrné, a tedy i méně důležité.

Zajímavý podnět k znovuotevření problému poskytuje ve své eseji věnované vztahu mezi Aristotelem a Baconem

spíše základem pro další badatelskou práci. Zároveň je však v takovém typu textu nutné zaujmout k danému autorovi jednoznačné stanovisko. Proto si oba autory vypůjčuji jako dobře viditelné protiklady.

Jedním z malých překvapivých objevů, ke kterému jsem se během četby Bacona dostala, je nečekaná citlivost Bacona jako filosofa. Tato citlivost se projevuje na více místech jeho díla, kde bychom očekávali jednoznačné hodnocení. Děkuji recenzentovi za připomínku, ve které mě upozorňuje na dalši možný a jednodušši způsob pojmenování tohoto jevu. Nemusí se jednat o citlivost, nýbrž o důkladnost Baconova pohledu, případně vyjádření jeho životních zkušeností.
Patočka, který tradiční vztah mezi nimi převrací. ${ }^{13}$ Důsledným aristotelikem se může jevit Bacon sám: „Nazveme-li aristotelismem snahu postihnout podstatu tohoto jediného reálného světa, pak Aristoteles je v očích Baconových nepravým, Bacon sám pravým aristotelikem. Jeho celý filosofický podnik může být pojat jako nový aristotelismus, pokus uspět tam, kde Aristoteles zklamal." ${ }^{14}$ Baconův plán nemusíme chápat nutně jako rozklad dosavadní filosofie a nastolení nové cesty, tedy tak, jak plán prezentuje sám Bacon, ale jako rekonstrukci filosofie.

\section{BACON A ARISTOTELÉS: DVA POzOROVATELÉ}

Rozdíl mezi oběma mysliteli tkví v antickém konceptu zkoumání ( $\theta \varepsilon \omega \varrho i ́ \alpha)$ a Baconově požadavku nového přístupu k teoretické vědě. Oba myslitelé podávají zcela odlišnou odpověd' na společnou

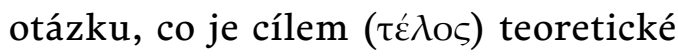
činnosti.

Aristotelés nás seznamuje s dělením lidských činností a jim odpovídajících věd například ve známé části Metafysiky VI, 1, 1025 b25. ${ }^{15} \mathrm{Z}$ dělení věd, které zde nalézáme, vyplývá, že pro Aristotela

13 Patočka 1964, s. 288-301.

14 Patočka 1964, s. 294.

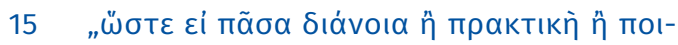

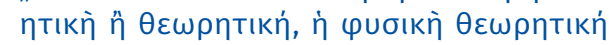

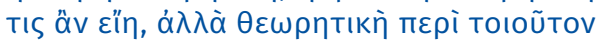

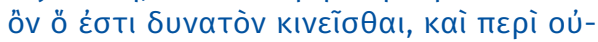

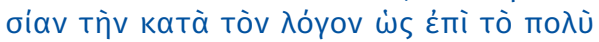

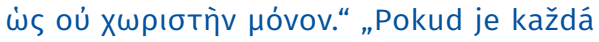
intelektuální činnost vědou praktickou, poetickou či teoretickou, přírodní filosofie bude vědou teoretickou; a to takovou teoretickou vědou, která pojednává o jsoucnu, kterým může být pohybováno, a jen o takové podstatě, která je dle 
teoretická činnost nemá jiného cíle, než je poznání samotné. Nabídnuté triadické schéma lidských aktivit není jen prázdným škatulkováním, právě naopak. Jedná se o koncentrované jádro Aristotelova přístupu. Aby byl člověk plně člověkem, musí pochopit, že jeho život se skládá z různých oblastí, které se liší svým cílem i způsobem, jakým je možné ho naplnit. Aristotelés však zároveň nenechává čtenáře dlouho na pochybách ohledně toho, která z aktivit člověka je nejzávažnější, ${ }^{16}$ a upomíná nás na to již první větou Metafysiky: Každý člověk od přirozenosti touží po vědění. ${ }^{17}$ Ačkoli Bacon Aristotela podezřívá z elitářství, nejedná se o činnost, která by náležela jen hrstce vyvolených (tj. mimořádně nadaných), ${ }^{18}$ nýbrž o činnost, která je odpovědí na přirozenou touhu zakotvenou v každém člověku. Teoretická činnost dělá ze člověka - živého organismu - plně rozvinutou lidskou bytost. ${ }^{19}$

svého výměru převážně neoddělitelná od látky." Př̀eklad KJ.

16 Svědectvím o výlučnosti teoretické činnosti ve srovnání s činností praktickou je X. kniha Etiky Níkomachovy. Praktická moudrost, jakkoli důležitá pro život člověka, podle Aristotela přece jen nedosahuje na stejnou přičku v hodnocení jako

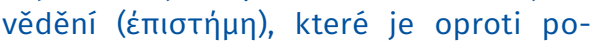
znatkům z oblasti etiky či politiky platné za všech podmínek. Tak i stav blaženosti

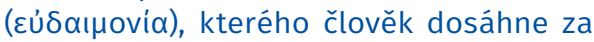
pomoci filosofie, je nejvíce žádoucí podobou blaženosti. Srov. Eth. Nic. X,7 1177a.

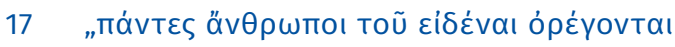

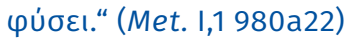

18 Teoretik je podezřiván z pyšnosti, z touhy strhnout na sebe pozornost (srov. NO I,67).

19 V českém prostředí se otázce vztahu mezi teoretickým věděním a moderním
Aristotelés nezapomíná, že člověk je tvorem, který sdílí s dalšími živými organismy stejné schopnosti: udržet se výživou a rozmnožováním, orientovat se ve světě za pomoci smyslů. S některými druhy sdílíme i nižší druhy představivosti. V tomto smyslu slova je člověk s dalšími živými tvory doslova na jedné lodi, jak ukazuje Aristotelés především ve svém spisu $O d u s ̌ i$. Je to teoretické rozvažování, co dělá ze živého organismu člověka.

Bacon si všímá plurality řeckých filosofických systémů a hodnotí ji spíše negativně. „Nelze opomenout také ten př́íznak, že mezi filozofy panoval kdysi značný nesouhlas a že byly velké rozdíly i mezi samými školami. Ukazuje to, že cesta od smyslů k rozumu nebyla dobře zajištěna, poněvadž týž předmět (rozuměj přirozenost věcí) se vláčel tak velikým množstvím rozmanitých omylů, že se v nich rozptýlil.“ (NO I,76) Bacon se snaží o vytvoření jednotného metodologického klíče, zatímco Aristotelés opakovaně upozorňuje (v těsné souvislosti s již zmíněným dělením věd), že ke každé oblasti lidského zájmu se hodí trochu jiné postupy, aby bylo možné dosáhnout poznatků.

Pro Bacona však vědění samo o sobě hodnotou není. Musí být užitečné, vyčíslitelné, a tím i kumulativní. A to ve jménu společného cíle: musí zajištovat člověku moc nad zkoumaným přírodním světem. Čím více se budeme vědě věnovat, tím více získáme poznatků,

pojetím vědy věnuje především Pavel Hobza v první části své knihy Filosofie a věda (Hobza 2015, především s. 11-30). 
které nás dovedou dál na cestě v poznání světa a jeho ovládnutí. ${ }^{20}$

Nárokem na užitečnost, vyčíslitelnost, kumulativnost dělá Baconův program $\mathrm{z}$ vědy práci. ${ }^{21}$ Počítá s celými generacemi badatelů, kteří budou v díle pokračovat, zatímco Aristotelova filosofie je dle Bacona individuálním výkonem. ${ }^{22}$ Výsledky kolektivní práce přináší možnost proměnit místo člověka ve světě. Člověk jako součást přírody, jako malý obraz světa ve světě kosmickém nemůže být jejím pánem, nýbrž obdivovatelem a pozorovatelem. „Vědění mělo sloužit nikoli tomu, aby

„Cílem osvícenství v nejobecnějším významu pokrokového myšlení od počátku bylo zbavit lidi strachu a učinit z nich pány.“ Adorno, Horkheimer 2009, s. 17.

Srov. Patočka 1964, s. 289-290.

Děkuji recenzentovi za poznámku, ve které upozorňuje na jistou násilnost Baconova hodnocení výkonů jeho předchůdců a způsobu teoretického života vůbec (ßíos $\theta \varepsilon \omega \rho \eta т$ тाќs). Bacon sice reflektuje (jak dále v textu zmiňuji) pluralitu řeckých filosofických systémů, ale nehodnotí toto prostředí primárně jako pozitivní podklad, na kterém dochází za pomoci dialogu ke generování nových myšlenek, ale spíše jako polyfonii zabraňující nastolení vědecké metody. Ačkoli Bacon dostatečně nedoceňuje prostředí antických poleis, jednotlivé filosofické doktríny řeckých myslitelů ve shodě s ním považuji taktéž spiše za plody ducha jednotlivce, ačkoli vždy zásadně spjaté s jeho intelektuálním okolím, které jej spoluutváří. Aristotelova filosofie je na jedné straně plodem dlouhé diskuse s predchůdci, přesto to neznamená, že by si formulování nového systému nežádalo zcela zásadního intelektuálního individuálního výkonu. Bacon pozitivní formující aspekt rozmanitého intelektuálního společenství podceňuje, ale i on sám je jeho dědicem. člověk vládl přírodě, nýbrž aby ji svým obdivem pomáhal udržovat ve stavu, v kterém odjakživa byla a jest - posláním člověka bylo sloužit této odvěké podstatě věcí, chránit ji, aby se v jeho duchu plně rozvíjela, a tak dovršovat harmonii světa."23 Antický myslitel je „služebníkem přírody“ (NO I,1). Baconova filosofie tento vztah mezi člověkem a přírodou mění. Člověk se má stát nad přírodou pánem.

Rozdíl mezi poznáním pro poznání samotné a poznáním jako mocí a s ním rozdíl mezi pozorovatelem světa a pozorovatelem-pánem je zřejmý. Nicméně oba pozorovatelé, Aristotelés i Bacon, společně sdílí principiální možnost poznání. Za oběma myšlenkovými systémy je cítit pozitivní étos. ${ }^{24}$ Poznání - a to jistého a nezpochybnitelného - člověk může dosáhnout, bude-li vyvíjet dostatečné úsilí. Liší se pak především v tom, jakými prostředky lze kýženého stavu dosáhnout. ${ }^{25}$

\footnotetext{
23 Patočka 1964, s. 290-291.

24 V tomto smyslu mohou být oba pochopeni jako osvícenci - nikoli ve smyslu historickém, nýbrž širším, tak jak o tomto přistupu člověka ke světu hovoří v již několikrát citované knize Adorno s Horkheimerem (2009).

$25 \vee$ textu explicitně nerozlišuji druhy غ́mıтท́ $\mu \eta$, tedy neformuluji rozdíl mezi věděním jakožto získaným stavem člo-

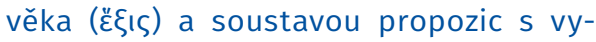
mezeným predmětem zkoumání. $V$ rámci studie v souvislosti s otázkou po metodě a především s Baconovým modelem vědy však pracuji především s významem druhým. Vědění jakožto získaný stav jedince odpovídá lépe Aristotelovu pojetí a zde v textu hraje spíše ilustrační roli. Jak již bylo řečeno, Baconův program nepočítá s jednotlivci, nýbrž s celým vědeckým společenstvím.
} 


\section{ARISTOTELOVY A BACONOVY JEDNOTLIVINY A FORMY}

Bacon si je vědom, že i dosavadní tradice přírodní filosofie se opírala o zkušenost. Ale způsob, jakým jeho předchůdci pozorovali přírodní svět, je pro něj zásadním způsobem nedostačující. Podle Bacona poznání získáme nikoli pouhým pozorováním, ale zasahováním do jevů a navrhuje pro tento účel používat předem připravené experimenty. ${ }^{26}$ Zkušenostní báze, na které se Baconův induktivní postup zakládá, nesmí být nahodilá. Nestačí pozorovat to, co se přirozeně ukazuje, je dokonce třeba donutit přírodní předměty $\mathrm{k}$ tomu, aby se chovaly nepřirozeně. Tak se chce Bacon dostat $\mathrm{k}$ vlastnostem, které za běžných okolností nejsou zjevné. ${ }^{27}$ Zdá se, že se tak prohlubuje rozdíl mezi dvěma pozorovateli z předchozího zamyšlení.

Vědci-předchůdci vycházeli podle Bacona jen z mála jednotlivých faktů. $\mathrm{S}$ tímto problémem se Bacon vypořádává za pomoci systematického a podrobného plánu. Zavádí srovnávací tabulky pro vybraný jev. ${ }^{28}$ Další výtkou je nedostatečné místo experimentu. Ačkoli pro Aristotela hrají př́íklady ze smyslově

Srov. NO I,70.

Přičemž na následky jednoho z nich zřejmě i zemřel. „Stal se - opět paradoxně jakousi obětí své vědecké vášně, protože se nachladil při experimentu, při němž zkoumal vliv sněhu v útrobách slepice na hnití jejího masa.“ (Zůna, Sobotka 1990, s. 12)

27 Proto se nástroji nové vědy mohou stát pitvy, pálení, chlazení atp. Srov. Špelda 2009, s. 86.

28 NO II,11-20. Srovnávací tabulky pro jev tepla zabírají převážnou část druhé části Nového organa a plní funkci modelového príkladu. poznatelného světa zásadní roli, experiment v Baconově smyslu slova u něj lze nalézt spíše výjimečně. ${ }^{29}$ Navíc u Aristotela nalézáme mnoho podob myšlenkového experimentu a také takové případy, které jsou na rozhraní mezi přírodovědným experimentem a úvahou. ${ }^{30}$ Bacon si těchto míst všímá a potvrzuje tak, že jeho zájem o Aristotelovo myšlení jej vede k poměrně podrobnému zkoumání. „Nikoho at' nemýlí to, že v jeho knihách O zvířatech, v Problématech a jiných jeho pojednáních se často mluví o pokusech. Své závěry učinil už napřed, přitom když tyto závěry vytvářel, nepoužil náležité zkušenosti, naopak, vyřešil věc zcela libovolně obecným tvrzením, a pak teprve překroutil zkušenost tak, aby těmto jeho tvrzením odpovídala, a vodil ji kolem nich jako svou zajatkyni." (NO I,63)

Na druhou stranu je třeba připomenout, že Aristotelés především ve svých přírodovědných pracích sám shromáždil množství faktů a jejich sbírání hraje roli i v dalších pojednáních. ${ }^{31}$ Nicméně je pravda, že otázka množství není pro Aristotela kritériem pro úspěšné poznání a v mnohých případech, jak ještě uvidíme dále, mu co do principu jako východisko postačuje jediný jev.

Induktivní cesta (غ̇ं $\alpha \gamma \omega \gamma \eta ́)$ je Aristotelovými slovy charakterizována následovně: postupujeme od toho, co je bližší

Na dva výskyty, oba z oblasti fysiologie, upozorn̆uje Lewes (1864, s. 112-113).

Jako jsou napřiklad ve spisu $O$ duši úvahy o tom, zda rozpůlený brouk je živý (tedy oduševnělý), či není, či zda je živý ještě po nějaký čas a poté umírá. Srov. DA I,5 411b19-24.

31 Srov. Dickie 1922, s. 474. 
nám, k tomu, co je zřejmé od přirozenosti. ${ }^{32}$ Tedy východiskem lidského poznání podle Aristotela jsou věci, které jsou přístupnější člověku ve světě, je to postup od věcí, se kterými se běžně stýkáme a kterým alespoň intuitivně rozumíme; od jevů v širokém smyslu slova. Naopak cílem je získání tzv. prvních principů, ačkoli jsou člověku méně známé a méně př́ístupné. Zjednodušeně bychom tento postup mohli nazvat jako cestu od jednotlivin k obecninám (An. Prior. I,30). $\mathrm{S}$ tímto předpokladem počítá ve svém metodologickém návrhu i Bacon: „U Bacona, stejně jako u Aristotela, je cílem věd nalezení principů, které jsou o sobě známější, a tedy, dřivější' než důsledky, jež na nich závisí. “33 Toto jádro svého, v podstatě metafysického, systému Bacon popisuje $\mathrm{v}$ prvních aforismech druhé části knihy Nové organon. ${ }^{34}$

Situace se zkomplikuje, pokud se zastavíme u toho, co to vlastně jev je. Nussbaumová upozorňuje v diskusi nad slavným Owenovým článkem ${ }^{35} \mathrm{v}$ aristotelském oddílu knihy Křehkosti dobra, jak široce jevy Aristotelés pojímá. Upozorňuje na řecký význam slova, kde jev je možné přetlumočit jako způsob, „jak se věc člověku ukazuje“. ${ }^{36}$ A tak ačkoli

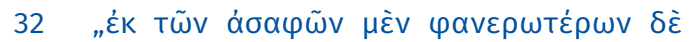

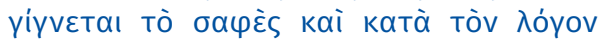

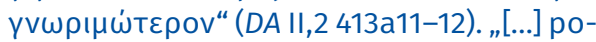
stupuje se od nejasného, ale zjevnějšího k jasnému a skrze logos pochopitelnějšímu [...]." Překlad KJ.

33 Röd 2001, s. 32.

34 O prvotnosti forem pojednává Bacon v aforismu NO II,4.

35 Owen 1986, s. 239-251.

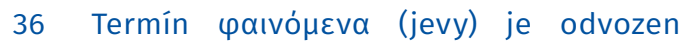

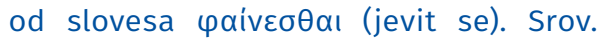
Nussbaumová 2003, s. 474-475. jevy zaujímají zásadní místo v Aristotelově procesu poznání jako nepostradatelná východiska či startovní body, jsou to přece jen jiné jevy, než které zajímají Bacona. Chceme-li situaci popsat krátce a výstižně, ukazuje se, že mezi tím, co se o věci říká (at již z pozice filosofické autority, či obecně sdíleného

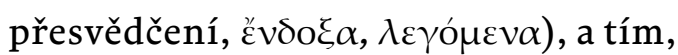
jak se nám věc jeví ( $\varphi \alpha$ เvó $\mu \varepsilon v \alpha)$, nemusí být zásadní rozdíl. ${ }^{37}$

Právě to, že obecně sdílené přesvědčení může být považováno za jev, a tedy za východisko poznání, je něco, co oba zkoumané myslitele od sebe oddaluje. ${ }^{38}$ Aristotelův záměr je jasně vyjádřen: $z$ tradice je třeba přijmout, co bylo řečeno správně, a vyvarovat se omylů našich předchůdců ( $D A$ I,2 403b23-24). Nicméně Bacon chce tuto linii zcela přetrhnout a vyslovuje požadavek obnovení věd od samých základů (NO I,31). Na učení o idolech můžeme

Srov. Nussbaumová 2003, s. 469-470.

38 "A happy characteristic distinguishing Bacon from Aristotle is the former's sceptical attitude towards popular opinion." (Dickie 1922, s. 479) Ačkoli Dickie sám ve svém textu $v$ rovině obecně prijímaných přesvědčení rovinu jevů nevidí, jeho text toto čtení umožňuje. Tedy Dickiemu není vlastní interpretační model, ve kterém lze jevy a názory považovat za výrazy do jisté míry synonymní (jak to vidí například Owen a Nussbaumová).

Aristotelés zdůrazňuje, že je potřeba z myšlení předchůdců vycházet. Konkrétní způsob, jakým Aristotelés zachází s předchůdci, je však předmětem neutuchajících debat, a to především pro svou radikalitu, kdy je podezřiván z toho, že myslitele poměřuje skrz vlastní filosofický systém.

Zásadní přispěvek k Aristotelovu vztahu k předchůdcům přinesla Chernissova kniha (Cherniss 1935). 
vidět, jak se Bacon zříká Aristotelovy snahy o to, vytěžit nejen dosavadní myslitele, ale také zůstat v kontaktu s tím, jak se o věcech běžně hovoří. ${ }^{39}$ Jak však již bylo předestřeno, je otázkou, nakolik se mu toto programové prohlášení daří naplnit a nakolik kontakt s tradicí, ačkoli negativně pojatý, jeho způsob myšlení určuje.

Principiálně se však v tomto bodě s Aristotelem rozcházejí. Za účelem objasnění tohoto problému uved'me Rödův popis Baconovy metody, kde ji shrnuje jako „[...] postup, jak vycházeje z dostatečného množství pozorování dospět k poznání obecných principů, které jsou základem pozorovaných skutečností “. ${ }^{40}$ Oba myslitelé by souhlasili s druhou částí popisu metody, tedy s dosažením obecných principů a s tím, že tyto obecniny určují jednotlivé věci ve světě. Rozhodně by se však neshodli v tom, jak může takový startovní bod poznání vypadat. Pro Aristotela by to mohlo být i jednoduché, obecně přijímané konstatování. Pro Bacona by se však mělo jednat o širší základnu, sérii množství experimentů spíše mechanického charakteru: „Pokud jde o práci, člověk nemůže nic jiného než k sobě přibližovat či od sebe oddalovat přírodní tělesa; ostatní udělá příroda sama, působíc uvnitř." (NO I,4)

Zajímavě o konvencionalismu a jeho místu v Aristotelově myšlení hovořil Pavol Labuda (2016). V našem kontextu je pak především zajímavá jeho úvaha o roli konvence při tvoření vědeckých definic. Labuda ukazuje, že ačkoli Aristotelovy výměry nejsou založeny pouze na konvenci, stále v sobě vědecký výměr obecně přijímaná tvrzení obsahuje.

Röd 2001, s. 32.
V Baconově spise však nalézáme i místo, které tuto jasnou odlišnost rozostřuje. „V mém popisu přírody a pokusů se vyskytují též mnohé věci, jež jsou bezvýznamné a obecně známé, dále všední a nízké a konečně příliš jemné a pouze spekulativní a zdánlivě neužitečné.“ (NO I,119) Tedy ani Bacon se nemůže zcela zbavit roviny obecně sdílených přesvědčení, dokonce ani tak kritizované spekulativnosti. Společný rys lze nalézt i v tom, že je potřeba vzít při zkoumání v potaz i věci triviální (jak Bacon říká, všední a nízké), aby nebylo nic při zkoumání opomenuto. ${ }^{41}$

Nejen Aristotelovy jevy mají několik podob, i samotná induktivní metoda má několik tváří. Bacon odhaluje zřejmě podobu tzv. induktivního sylogismu (např. An. Prior. II,23; An. Post. I,5). V tomto typu úvahy můžeme podle Aristotela dojít k nalezení odpovědi (stanovení obecného závěru), aniž by bylo nutné ověřovat všechny jednotlivé př́íklady. ${ }^{42}$ Souvisí to s metafysickým předpokladem Aristotelovy filosofie. Znát jednotlivinu znamená zároveň vědět, že v sobě zahrnuje obecninu. Dále je tu typ induktivní úvahy, která se označuje jako dialektická indukce (např. Top. I,18; VIII,2). Takové uvažování nalézá pravdivé obecné tvrzení pro praktické účely. A tedy postačuje, že bylo nalezeno mnoho případů $\mathrm{k}$ potvrzení a žádný k vyvrácení. Tyto typy induktivních úvah odhaluje ve svém

41 Srov. Nussbaumová 2003, s. 482-483.

42 Podle Aristotela to ani není možné, ale především prostý výčet nezaručuje jistotu (An. Post. I,5). 
článku Dickie v souladu s dalšími badateli. ${ }^{43}$

Ale je otázkou, zda nabídnuté podoby indukce vyčerpávají Aristotelovu $\varepsilon \dot{\epsilon} \alpha \gamma \omega \gamma \eta ́$. Lze si jen těžko představit, že by se výše zmíněnými postupy člověk dostal k poznání principů, těch, co jsou cílem lidské teoretické aktivity. Proto se zdá nosný přístup Hobzy, který induktivní metodu vysvětluje jako označení pro celý soubor postupů, které Aristotelés ve svých spisech používá. ${ }^{44}$ Důležité pro potřeby našeho zamyšlení je, že ve všech po-


ňuje na důležitost jevů jako východisek (např. De Part. An. I,1, 639).

Bacon kritizuje Aristotelovy chybné závěry a připisuje problém nedostatečné základně pozorování. Bacon v Aristotelově indukci vidí postup vycházející z prostého a neúplného výčtu, a proto proti ní staví indukci svoji jako druhou cestu (NO, I,19-22). Za „uspěchaná zobecnění “ však Aristotela napadají i moderní badatelé. ${ }^{45}$ Tyto námitky jistě mají opodstatnění v případě jednotlivých úsudků, které se dnes mohou zdát úsměvné s ohledem na nové poznatky například na poli biologie. Ale je to sám Aristotelés, kdo principiálně upozorňuje na chybná zobecnění, prázdné generalizace, které jdou proti jevům. Je tedy evidentní, že pokud by výsledek našeho poznání nekorespondoval s tím, jak se věci člověku jeví, nemohl

43 Srov. Dickie 1922, s. 471-479. Srov. např. s Irwin 1988, s. 323-325, 337-339.

44 Hobza 2016.

45 "Aristotle frequently 'rushes to conclusions'." (Dickie 1922, s. 476) by si činit nárok na pravdivost. ${ }^{46}$ Dickie, který ve svém textu pohlíží spíše kriticky na Aristotelovy konkrétní postupy s důrazem na chybné závěry, vyzvedává, že i přes jednotlivé chyby Aristotelés dosahuje něčeho velmi podstatného. Jeho induktivní postup dává vzniknout obecnému ve smyslu hypotézy, tvrzení o skupině věcí. ${ }^{47}$

Proto poslední část textu bude zaměřena na hledání obecného, na formulování toho, co je zkoumaným jevům společné. Tento rys hraje stěžejní roli v myšlení obou autorů. Bacon překvapivě při označování obecného používá stejného pojmu jako Aristotelés: je jím forma. Jistou roli může hrát to, že je pojem znám a běžně užíván. Podobnost však nekončí shodou v označení. Především zde nalézáme shodné metafysické přesvědčení, že existují formy poznání, které můžeme svým rozumem uchopit. Poznání je tak pro oba poznáním existujících struktur. „Indukci Bacon zjevně považuje za jistý druh odvozování, s jejíž pomocí lze získat nehypotetické obecné věty, případně zákony. " ${ }^{48}$

Tohoto rysu si všímá Röd a upozorňuje, že Baconův systém stojí minimálně zčásti na Aristotelových předpokladech. ${ }^{49}$ Baconův projekt induktivního modelu vědy je založen na tom, že kromě konkrétních věcí existují také obecniny, tj. formy. Tyto obecniny nejsou od

Napřiklad výměr duše obsáhne všechny živé, tj. oduševnělé, tvory.

“[...] several facts more or less unlike being grouped under one idea." Dickie 1922, s. 479.

48 Röd 2001, s. 33.

49 Röd 2001, s. 24. 
konkrétních věcí oddělené, ale jsou spíše imanentním strukturním principem. „Jeho indukce tedy stojí Aristotelově epagogé blíže, než se autor Novum Organum domníval. “" ${ }^{50}$ Proto i Baconova kritika Aristotelova pojmu formy je poměrně problematická. Je především založena na podezření, že Aristotelovy termíny byly Aristotelem dopředu vytvořeny a nejsou výsledkem procesu poznání (např. NO I,15). Explicitně řečeno, Bacon se domnívá, že Aristotelovy filosofické pojmy jsou konstruktem bez přímé vazby k pozorovaným jevům.

Podle Bacona člověk není schopen v jednotlivých věcech rozumem postihnout obecninu, nemůže ji nahlédnout. Proto badatelé zdůrazňují, že obecné je u něj odvozováno spíše nepřímo, vyloučením, a zdůrazňují tak především eliminativní rys Baconovy metody. Ta funguje především na základě analýzy toho, co je dané, a vyloučením toho, co k podstatě jevu nepatřrí. ${ }^{51}$ „[...] indukce, jíž se dá užít ve vědách a uměních jako metody vedoucí $\mathrm{k}$ objevům, musí analyzovat přírodu tím, že patřičně odmítá a vylučuje, a teprve potom, když je $\mathrm{k}$ dispozici dostatečný počet záporných případů, usuzovat na příklady kladné.“ (NO I,104). ${ }^{52}$ Nicméně i Aristotelés, když vybírá mezi jevy, provádí určitou selekci, jak je dobře patrné na jeho práci s myšlením předchůdců.

Každá jednotlivá věc v Baconově systému je určena několika málo základními vlastnostmi, ty jsou předmětem

50 Röd 2001, s. 32.

51 Srov. Röd 2001, s. 33 a dále srov. Jardine 2000, s. xxi.

52 Dále srov. např. NO I,16, 18. zkoumání. At' se již jeví pozorovaný objekt jakkoli rozmanitý a komplikovaný, lze za pomoci této Baconovy optiky odhalit v každé věci soubor několika málo podstatných vlastností, které ji určují. Příkladem takové jednoduché vlastnosti je teplo, na kterém Bacon svůj postup předvádí (NO II,11). Baconovu formu tak můžeme pochopit jako obecný výměr, v němž jsou zohledněny všechny jednoduché vlastnosti přírodního objektu.

Znamená to, že Bacon s Aristotelem sdílí přesvědčení, že forma musí do sebe zahrnovat všechny jednotlivé zástupce. A tak Bacon splňuje Aristotelův požadavek na definici, obecný výměr, který je vzhledem k jednotlivinám zcela vyčerpávající. Interpreti se snaží zdůrazňovat, že u Bacona jde o mikrostrukturu hmotné věci. Ale stejně tak Aristotelés upozorňuje, že neexistuje koule bez vnímatelné koule či dům mimo domu $\mathrm{z}$ cihel (Met. VII, 8 1033b20-21).

Je tedy nějaký zásadní rozdíl mezi formou Aristotelovou a Baconovou? Zdá se, že největší diference zřejmě zůstává v tom, co s formou učiníme, pokud jejího poznání dosáhneme. Sám Bacon upozorňuje, že Aristotelova forma umožňuje jen výklad věci, nikoli ovládnutí př́írody (NO II,1). U Bacona oba tyto aspekty splývají v jedno. Patočka ukazuje, že Aristotelova forma spíše poukazuje na to, čím se daná věc podílí na tom, co je neměnné a trvalé, zatímco Baconova forma spíše ukazuje účast věci na dynamismu světa. ${ }^{53}$ Pokud

53 Na druhou stranu Aristotelova filosofie používá různé pojmové sady, aby se vypořádala s uchopením procesů ve světě. 
ji dokážeme vyložit, pak ji dovedeme také realizovat. Tedy Baconova forma překračuje hranici mezi teorií a jejím využitím. ${ }^{54}$ Právě v tomto rysu spatřuje Patočka základní kámen Baconova projektu. „[...] rozvrh lidského vědění, tato velká anticipace moderní soustavy věd, není Baconem pojata jako protiklad a rozklad dosavadní filosofie, nýbrž jako její rekonstrukce na základě radikální reformy myšlenkou poznání účinného, pracujícího, metodického.“55

Nabízí se možnost změkčení původního ostrého rozdílu mezi teorií a praxí, ke kterému mě opět přivádí Rödovy poznámky. Na začátku jsem využila schéma, v němž jsem postavila Aristotela jako kontemplativního vědce proti Baconovi jako propagátorovi praxe. Röd upozorňuje na to, že ani Baconovu vědu nelze provádět pouze za účelem zisku. K vysvětlení si půjčuje Baconův obraz systému věd jako stromu, kde „části lidského vědění se $\mathrm{k}$ sobě mají jako části stromu, které mají všechny stejně důležitou funkci, i když ovoce nesou jen větve. Je také nutné starat se o kořeny, chceme-li sklízet plody“ ${ }^{56}$ A jeho úvaha pokračuje dál, ani v oblasti speciálního

Jednotlivou věc lze popsat nejen za po-



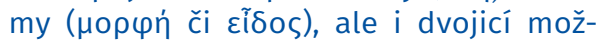


Odpovídají jen z jiného úhlu na stejnou otázku, kterou je vysvětlení jednotlivé věci ve světě. Vznik věci, zánik a její různé stavy jsou popisovány prostřednictvím poměrně rozmanitého pojmového slovníku, za jehož pomoci dojde k objasnění vždy určitého aspektu zkoumaného problému (jevu).

54 Srov. Patočka 1964, s. 296.

55 Patočka 1964, s. 300.

56 Röd 2001, s. 42. Srov. NO I,80. výzkumu není kritériem bezprostřední užitek. Ve prospěch tohoto tvrzení pak hrají ty Baconovy úvahy, v nichž je dána přednost experimentům, ve kterých dojde $\mathrm{k}$ objasnění problému, před experimentem užitečným, tj. takovým, jehož výsledek je okamžitě převeditelný do praxe. ${ }^{57}$

\section{DĚDIC \\ BACON JAKO ARISTOTELŮV}

Nabídla jsem čtenáři takový pohled na Bacona a Aristotela, v němž mnohé rozpory mezi jedním a druhým autorem nejsou vlastně rozpory, ale spíše snahou o jiné řešení. Řešení, které se asi nejvíce liší tím, $\mathrm{k}$ jakému cíli směřuje. Baconův projekt se tak dle nabídnutého čtení děje ve znamení těsného dialogu s předchůdci, s Aristotelem především.

Na podporu toho, proč lze považovat Bacona spíše za Aristotelova dědice nežli odpůrce, byla v textu uvedena řada příkladů. Jejich společným rysem je, že na první pohled nesmiřitelné protiklady mezi jedním i druhým myslitelem jsou rozmělňovány, rozdíly nejsou ve své původní radikální podobě udržitelné. Nejdůležitější přitom je, že je to Bacon sám, kdo čtenáře dovádí $\mathrm{k}$ takovému způsobu čtení.

Stručně to lze ilustrovat za pomoci dvou hlavních bodů, na kterých byla v textu primárně ukázána rozdílnost obou myslitelů. Prvním je otázka místa a cíle teoretických věd, která tvoří jakési jádro, ze kterého oba projekty, Aristotelův i Baconův, vyrůstají. Za pomoci 
metafory dvou různých pozorovatelů bylo ve studii ukázáno, že ani rozdíl mezi teoretickou činností jakožto vlastním cílem a teoretickou činností jakožto prostředkem k získání moci nezůstává v Baconově filosofickém projektu v této radikální podobě. Vedou $\mathrm{k}$ tomu $\mathrm{Ba}-$ conovy úvahy, ve kterých zvažuje roli objasňování určitého problému a zisku z něj plynoucího (NO I,121), či takové myšlenky, kde zdůrazňuje nutnost péče o teoretickou činnost, chceme-li vůbec pomýšlet na sklízení plodů specializovaných věd (NO I,80).

Druhým reprezentativním př́íkladem rozdílnosti mezi Baconem a Aristotelem je otázka východisek poznání. Zatímco Baconův pozorovatelný fakt lze jednoduše začlenit do širšího označení jevů v rámci Aristotelovy filosofie, obráceně je to již velmi problematické. A to především proto, že pro Aristotela se může východiskem, tj. startovním bodem poznání, stát i jeden obecně zastávaný názor. I zde se však Baconův postoj rozostřuje a ukazuje se, že i jeho způsob bádání rovinu zdánlivě nepodstatného a obecně známého obsahuje (NO I,119).

Projekt jednotné metody Bacona samotného vede $\mathrm{k}$ principiálnímu odmítání předchůdců, kteří pro něj ztělesňují mnohost a nejednoznačnost přístupů ke zkoumání světa. Dialektický vztah $\mathrm{k}$ předchůdcům však způsobuje, že se $s$ nimi nemůže vypořádat jednou a provždy, ale naopak se diskuse s nimi stává vlastní součástí jeho myšlení a filosofického systému. Jediná možnost, jak se s komplikovaným dědictvím vypořádat, je jeho vědomá reflexe. Komplikovanost vztahu mezi předchůdci a Baconem se nejlépe vyjevuje na konkrétní rovině. To je patrné především při srovnání Aristotelova a Baconova metafysického systému, které nesou zásadní podobnosti. 


\section{Aristotelés}

An. Post. Analytica posteriora

An. Prior. Analytica priora

DA De anima

De Part. An. De partibus animalium

Eth. Nic. Ethica Nicomachea

Met. Metaphysica

Top. Topica

\section{ZKRATKY}

\section{Francis Bacon}

NO Novum Organum

DK Diels, H., Kranz, W. (1969). Die Fragmente der Vorsokratiker. 6. Aufl. Zürich: Weidmann.

\section{BIBLIOGRAFIE}

Adorno, T. W., Horkheimer, M. (2009). Dialektika osvícenství. Praha: OIKOYMENH.

Andersen, H., Hepburn, B. (2016). „Scientific Method“. In: E. N. Zalta (ed.), Stanford Encyclopedia of Philosophy. Dostupné [online] z: <https://plato.stanford. edu/archives/sum2016/entries/scientific-method/>.

Aristotle (1924). Metaphysics (Greek) (ed. W. D. Ross). Perseus Digital Library. Oxford: Clarendon Press.

Bacon, F. (1990). Nové organon (přel. M. Zůna). Praha: Svoboda.

Bacon, F. (2000). The New Organon (eds. L. Jardine, M. Silverthorne). Cambridge Texts in the History of Philosophy. Cambridge: Cambridge University Press.
Dickie, W. M. (1922). „A Comparison of the Scientific Method and Achievement of Aristotle and Bacon". The Philosophical Review 5, s. 471-494.

Epagógéa Epistémé (2004). Praha: Petr Rezek.

Hicks, R. D. (1907). Aristotle, De Anima with translation, introduction and notes. Cambridge: Cambridge University Press.

Hobza, P. (2015). Filosofie a věda: filosofické pojednání o skutečnosti. Praha: OIKOYMENH.

Hobza, P. (2016). „Aristotelova filosoficko-vědecká metoda“. Konferenční příspěvek pronesený na kolokviu Aristotelés a jeho dědictví, pořádaném Katedrou filozofie Filozofické fakulty Univerzity Palackého v Olomouci a Českou společností pro studium Aristotela a jeho myšlenkového odkazu, dne 9.12. 2016. 
Cherniss, H. F. (1935). Aristotle's Criticism of Presocratic Philosophy. Baltimore: Johns Hopkins Press.

Irwin, T. (1988). Aristotle's first principles. Oxford: Clarendon Press.

Jardine, L. (2000). Introduction. In: F. Bacon, The New Organon (eds. L. Jardine, M. Silverthorne). Cambridge Texts in the History of Philosophy. Cambridge: Cambridge University Press.

Labuda, P. (2016). „Aristotelova filozofia jazyka: posun smerom k pragmatickejšiemu čítaniu“. Konferenční příspěvek pronesený na kolokviu Aristotelés a jeho dědictví, pořádaném Katedrou filozofie Filozofické fakulty Univerzity Palackého v Olomouci a Českou společností pro studium Aristotela a jeho myšlenkového odkazu, dne 9.12. 2016.

Lewes, G. H. (1864). Aristotle: A Chapter from the History of Science, Including Analyses of Aristotle's Scientific Writings. London: Smith, Elder and co.

Matthews, S. (2008). Theology and Science in the Thought of Francis Bacon. Burlington: Ashgate.

Nussbaum, M. C. (1986). Logic, Science and Dialectic. Ithaca, N.Y.: Cornell University Press.
Nussbaumová, M. C. (2003). Křehkost dobra: Náhoda a etika $v$ recké tragédii a filosofii (přel. D. Korte). Praha: OIKOYMENH.

Owen, G. E. L. (1986). „Tithenai ta phainomena“. In: M. C. Nussbaum (ed.), Logic, Science and Dialectic. Ithaca, N. Y.: Cornell University Press.

Patočka, J. (1964). Aristotelés, jeho předchůdci a dědicové. Praha: Nakladatelství Československé akademie věd.

Ráliš, J. (2010). Věda, principy a dialektika $v$ Aristotelově díle (magisterská diplomová práce). Olomouc: Univerzita Palackého v Olomouci.

Röd, W. (2001). Novověká filosofie. Praha: OIKOYMENH.

Špelda, D. (2009). Renesanční a novověká filosofie. Plzeň: Západočeská univerzita v Plzni.

Špelda, D. (2016). Pravda-dcera času. O původu ideje pokroku poznání. Červený Kostelec: Pavel Mervart.

Zůna, M., Sobotka, M. (1990). Úvodní studie. In: F. Bacon, Nové organon. Praha: Svoboda. 